detected. But the CDMS detector is only around 10 metres below Stanford University's campus, and background noise was too high for researchers to draw unambiguous conclusions.

The latest results were obtained by researchers working on the Edelweiss detector at the Modane Underground Laboratory, located 1,700 metres below the Alps.

Edelweiss has lower levels of background noise than the CDMS detector. And, by virtue of using germanium instead of iodine, it is more sensitive than DAMA. Germanium allows the measurement of two properties of any potential interactions - temperature change and an ionization signal — rather than just one.

"The results reported by the DAMA team could have been generated by background events or could have been statistical fluctuations," says Gilles Gerbier of the Saclay Centre of the French Atomic Energy Commission near Paris, and a member of the Edelweiss collaboration.

Other researchers agree. "The DAMA results were hard to believe, but also hard to disprove. The Edelweiss results are very convincing," says Yorck Ramachers, who works on another dark-matter experiment at Gran Sasso. But Bernabei is sticking to her guns, insisting that the DAMA WIMPs are real, and that experiments using different detectors are not comparable.

The search for WIMPs with other characteristics will go on. Edelweiss will be able to extend its search after two more detectors are installed in the next nine months - a total of 21 will be online by the end of 2003. In addition, the CDMS experiment will soon move to a deeper site in north Minnesota.

http://edelweiss.in2p3.fr

\title{
South African cabinet backs merger plan for universities
}

\section{Michael Cherry, Cape Town}

South Africa is to proceed with a controversial plan to merge institutes of higher education that taught blacks and whites separately under apartheid (see Nature 417, 377-378; 2002).

The cabinet accepted the merger plan late last month after Kader Asmal, the education minister, made concessions that will allow two of the nation's best-known historically black universities - the University of the Western Cape and the University of Fort Hare - to retain their separate identities.

The country's 21 universities and 15 technikons (polytechnics) will now be streamlined into 11 universities, 6 technikons and 4 comprehensive institutions that will offer both university and technikon programmes. The government says that this will create "a system that is equitable, academically and financially sustainable, and productive".

The government also hopes to counter falling registration numbers by increasing the participation rate - the percentage of 20-24-year-olds enrolled in higher education - from $15 \%$ to $20 \%$ over the next 10 years. This will involve an estimated additional 200,000 students, most of whom will need to be supported by increased government allocations to the National Student Financial Aid Scheme - although the government also hopes to recruit more students from other countries in the region.

The South African government is also committed to reducing the percentage of

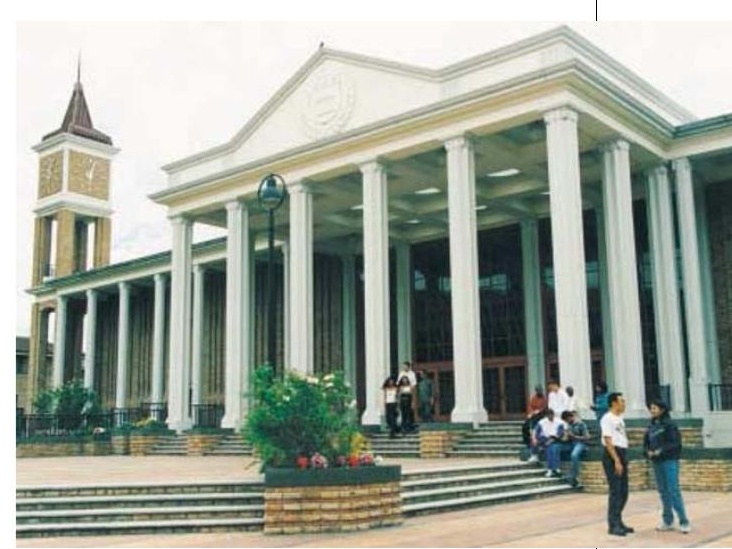

The historically black University of the Western Cape is set to retain its separate identity.

enrolments in the humanities from $49 \%$ to $40 \%$ over the next five to ten years, while increasing those in business or commerce from $26 \%$ to $30 \%$, and those in science, engineering and technology from $25 \%$ to $30 \%$.

Derrick Swartz, rector of the University of Fort Hare, said in a statement that the cabinet's decision had vindicated its long campaign against the merger, and that he hoped it would make the "new Fort Hare the major player in the region". But others were less satisfied. "These are senseless proposals that amount to merely tinkering with the status quo," Itumeleng Mosala, Rector of the Technikon North-West and chairman of the Association of Historically Disadvantaged Institutions, told the Johannesburg daily Business Day.

\section{Chinese researcher accused of stealing cell samples}

Rex Dalton, San Diego

A Chinese-born scientist has been held in a Californian jail for nearly three weeks, after being arrested for allegedly stealing materials and methods used to grow corneal cells which, police files claim, he intended to export to China.

Veterinary researcher Bin Han was jailed on 17 May after police searched his home and found records of stem-cell experiments and serum samples allegedly misappropriated from the University of California, Davis, where he is employed. They also found a ticket for a round-trip to China for the following week.

The jailing of Han - who was born in China but has been a US citizen since 1999 - is the latest example of the increasingly hard line US authorities are taking with researchers who stand accused of exporting biological samples or information without permission. Last May, for example, two Japanese researchers were charged with industrial espionage for their alleged involvement in such exports (see Nature 411, 225-226; 2001).

At a state court hearing on 4 June in a suburb of Sacramento, California, a judge allowed Han to be released after authorities had taken possession of his passports. Han now faces a preliminary hearing on 16 July on at least one felony charge of embezzlement.

Since 1990, Han has worked in various laboratories at the University of California, Davis, after coming to the United States in 1989. During one period, according to university records, he also said he was running an investment firm on behalf of Chinese financiers.
Two years ago, Han became a postdoctoral fellow in the laboratory of ophthalmologist Ivan Schwab and dermatologist Rivkah Isseroff — who are investigating how to make stem cells grow into corneal epithelial cells to replace damaged eye tissue. The technique might also have wide application for making other epithelial cells, researchers say.

Early last month, court records show, officials at the University of California, Davis, became suspicious of Han after learning that he was setting up a stem-cell research laboratory in China, where he frequently travelled. Police raided Han's home after vials of human sera used in Schwab and Isseroff's research went missing.

If convicted, Han could face a prison term. Neither he nor his attorney could be reached for comment. 